\title{
Effects of the Pilates method isolated and associated with manual therapy in women with urinary incontinence
}

\author{
Stephany Gordon, Daniele Bastos Ruivo, Luciana Gonzalez Auad Viscardi, Adriana Sarmento de Oliveira.
}

Universidade Anhembi Morumbi, São Paulo, (SP), Brazil.

\begin{abstract}
Background: Urinary incontinence (UI) is clinically defined by the International Continence Society as involuntary urine loss. Currently, UI is considered a public health issue worldwide, considering that the prevalence in women is quite high, requiring attention from health professionals. Objective: To evaluate the effects of the Pilates method associated with Manual Therapy in women with UI. Methods: It was performed a randomized, controlled, longitudinal clinical trial with a quantitative approach of the data. 14 female participants were evaluated, aged 20 to 55 years and who had presented episodes of urinary loss in the last months. The following evaluations were carried out: anamnesis, evaluation of urogynecological history, application of the King's Health Questionnaire and PERFECT test. After all the evaluations, half of the volunteers received treatment for urinary incontinence through a physical therapy approach that includes the Pilates method associated with Manual Therapies (GPT), and the other half received treatment using only the Pilates method (GP). Results: Both groups showed increased PFM strength, being GPT $(p=0.04)$ and GP $(p=0.00)$; increased resistance, being GPT $(p=0.02)$ and GP $(p=0.01)$; and the contraction of fibers, being GPT $(p=0.04)$ and GP $(p=0.02)$. In the GPT there was a decrease in the severity measures $(p=0.01)$; disappearance of nocturia $(p=0.04)$; decreased symptoms of SUI $(p=0.02)$; and bladder pain $(p=0.04)$. In the GP, there was a significant improvement in the perception of health $(p=0.00)$; decreased UI impact on the participant's life $(p=0.02)$; the influence of UI on emotions $(p=0.00)$; symptoms of overactive bladder $(p=0.01)$; and the SUI $(p=0.00)$. Conclusion: Both treatment protocols decrease episodes of leakage of urine when there is an increase in intra-abdominal pressure, increase the PFM strength, endurance and number of fast contractions, and the quality of life of women with UI. However, only the group that received only the Pilates protocol showed an increase in repetitions of slow contraction. Keywords: Physiotherapy; Women's Health; Urinary Incontinence; Pelvic Floor; Pilates; Manual Therapies.
\end{abstract}

\section{BACKGROUND}

Urinary incontinence (UI) is clinically defined by the International Continence Society (ICS) as involuntary urine loss ${ }^{(1)}$. Currently, $\mathrm{UI}$ is considered a public health issue worldwide, considering that the prevalence in women is quite high, requiring attention from health professionals. According to the Brazilian Society of Urology (SBU), UI affects more than 10 million people in the country, being a problem twice as common in women, and after menopause, about $35 \%$ of women have some degree of dysfunction ${ }^{(2)}$.

It is estimated that only one in four women with symptoms of urinary loss seek medical help, even if it affects the quality of life devastatingly ${ }^{(3-5)}$. Therefore, UI ends up being underdiagnosed and undertreated $^{(6)}$. The causes that lead to stress urinary incontinence (SUI) may be due to intrinsic sphincter deficiency of the urethra and hypermobility of the bladder neck. The intrinsic sphincter deficiency of the urethra occurs due to a failure in the mechanism of coaptation or urethral closure, whereas the hypermobility of the bladder neck comes from a change in the urethrovesical junction during the increase in intra-abdominal pressure ${ }^{(7-9)}$. Pilates method has stood out with beneficial effects in increasing the contractility and pressure of the pelvic floor muscles in young, climacteric women and also elderly women with pelvic floor muscle disorders ${ }^{(10,11)}$. Because it is a method composed of exercises that involve isotonic contractions (concentric and eccentric) and, mainly, isometric of the abdominal, transversus abdominis, multifidus and pelvic floor muscles (PFM), which are responsible for the static and dynamic stabilization of the body. It is believed that this method can produce a significant increase in the contractility of this musculature, being an alternative for the treatment and prevention of PFM dysfunctions ${ }^{(12,13)}$.

Additionally, manual therapies are presented as another alternative to complementary UI therapy. Used for musculoskeletal rebalancing, the joint and soft tissue manipulations and mobilizations present in manual therapies are an additional benefit to women with SUI, which can then enhance body and pelvic awareness, alignment and improvement of pelvic mobility acquired with Pilates ${ }^{(14)}$. Therefore, the objective of this study was to evaluate the effects of the Pilates method associated with Manual Therapy in women with urinary incontinence.

\section{METHODS}

This is a randomized, controlled, longitudinal case study with a quantitative approach to the data, carried out at Universidade Anhembi Morumbi da cidade de São Paulo (SP), Brazil, 
with the data collected by the researcher at the Integrated Health Center of the University from October to November 2019. Fourteen female volunteers, aged between 20 and 55 years, participated in this study, who presented complaints, symptoms and/or reports of urinary loss, without functional limitations that prevent physical activity. The study excluded women who were menopausal, diabetic, who used diuretic drugs, benzodiazepines or any other that alters the neurophysiology of urination, who present acute neurological signs, musculoskeletal pathologies that prevented the performance of exercises.

\section{Procedures}

The volunteers underwent a general physical evaluation and answered the King's Health Questionnaire (KHQ), a test that assesses quality of life in urinary incontinence. Participants who met all the inclusion criteria and agreed to participate in the study were subjected to the PERFECT pelvic functionality test. Randomization was performed using sealed envelopes and the sample was divided into two groups of 7 participants:

PTG: Pilates group associated with manual therapy, consisting of 20 minutes of the manual therapy protocol used by Oliveira et al. ${ }^{(15)}$, and after that, 40 minutes of pelvic floor awareness exercises and Pilates protocol used by Souza et al. (15).

PG: Pilates Group, which performed 40 minutes of pelvic floor awareness exercises and Pilates method exercises used by Souza et al. ${ }^{(12)}$.

Both groups were submitted to 10 sessions. The data were organized in spreadsheets on the Microsoft Office Excel 2010 software, submitted to the Student test with a 95\% confidence interval and $p<0.05$ significance and the results were analyzed quantitatively and presented in tables and graphs.

\section{RESULTS}

The clinical and physical characteristics of the PTG and PG groups are shown in Table 1. The groups were similar in terms of gender, age, body mass index (BMI), type of UI, length of complaint of the participant, previous pelvic physiotherapy treatment, comorbidities, number of pregnancies, type of delivery, number of daily protective pads used and the practice of regular physical exercise.
Table 1. Clinical and physical characteristics of the pre-intervention groups.

\begin{tabular}{|c|c|c|}
\hline & $\begin{array}{l}\text { PTG } \\
(n=7)\end{array}$ & $\begin{array}{l}\mathrm{PG} \\
(\mathrm{n}=7)\end{array}$ \\
\hline Age (years) & $35 \pm 4.04$ & $37.1 \pm 5.1$ \\
\hline $\mathrm{BMI}\left(\mathrm{kg} / \mathrm{m}^{2}\right)$ & $27.5 \pm 2.5$ & $24.9 \pm 1.6$ \\
\hline Type of IU & & \\
\hline IUE & (6) $85.7 \%$ & (5) $71.4 \%$ \\
\hline IUM & (1) $14.2 \%$ & (2) $28.5 \%$ \\
\hline $\begin{array}{l}\text { Complaint time } \\
\text { (months) }\end{array}$ & $25.7 \pm 15.8$ & $15.4 \pm 3.1$ \\
\hline $\begin{array}{l}\text { Previous } \\
\text { physiotherapy }\end{array}$ & & \\
\hline No & (5) $71.4 \%$ & $71.4 \%$ \\
\hline $\begin{array}{l}\text { Yes } \\
\text { Comorbidities }\end{array}$ & (2) $28.5 \%$ & (2) $28.5 \%$ \\
\hline Allergic Rhinitis & (2) $28.5 \%$ & (3) $42.8 \%$ \\
\hline Asthma & 保 & (1) $14.2 \%$ \\
\hline $\begin{array}{l}\text { Intestinal } \\
\text { Constipation }\end{array}$ & (2) $28.5 \%$ & (2) $28.5 \%$ \\
\hline $\begin{array}{l}\text { Pregnancy }\left(\mathrm{n}^{\circ}\right) \\
\text { Types of birth }\end{array}$ & $1 \pm 0.53$ & $1 \pm 0.4$ \\
\hline $\begin{array}{l}\text { normal birth } \\
\text { (with } \\
\text { episiotomy) }\end{array}$ & (1) $14.2 \%$ & (1) $14.2 \%$ \\
\hline cesarean & (2) $28.5 \%$ & (3) $42.8 \%$ \\
\hline none & (4) $57.1 \%$ & (3) $42.8 \%$ \\
\hline $\begin{array}{l}\text { Tampon per day } \\
\text { Regular physical } \\
\text { exercise } \\
\text { practitioner }\end{array}$ & $2.4 \pm 1.06$ & $2.4 \pm 0.7$ \\
\hline Yes & (6) $85.7 \%$ & (4) $57.1 \%$ \\
\hline No & (1) $14.2 \%$ & (3) $42.8 \%$ \\
\hline
\end{tabular}

Figure 1 shows when urinary losses occurred before and after intervention with the manual therapy and Pilates protocols in the PTG.

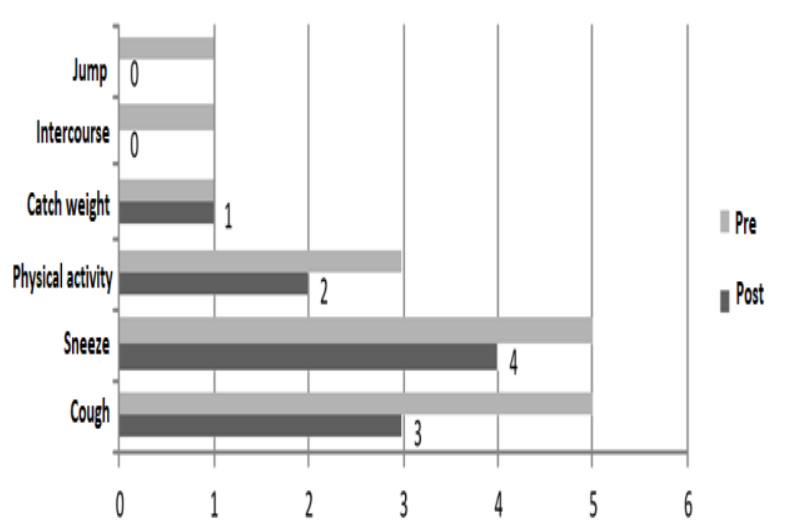

Figure 1. Pilates group associated pre and post intervention. 
Figure 2 shows the moments when urine leakage occurred in the pre and post intervention periods of the GP.

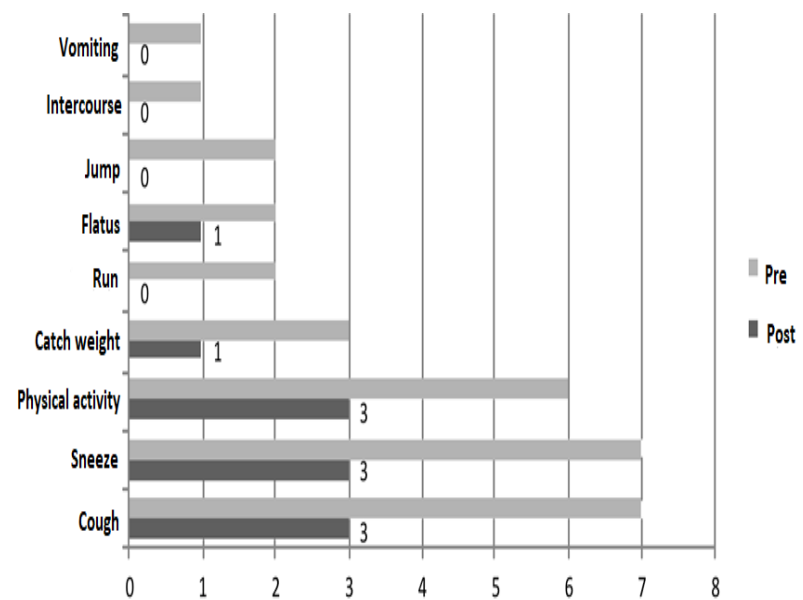

Figure 2. Pilates group pre and post intervention.

Regarding the improvement of pelvic functionality, assessed through the PERFECT test, there was a significant difference for the two groups in different variables, as shown in Table 2. Both groups showed an increase in the PFM strength, being PTG $(p=0.04)$ and PG $(p=$ $0.00)$; both groups showed an increase in resistance, being PTG $(p=0.02)$ and $P G(p=$ 0.01 ); only the $P G$ showed an increase in the variable $R$ repetitions $(p=0.00)$; both had improvement in the contraction of fibers, being PTG $(p=0.04)$ and PG $(p=0.02)$.

Table 2. PERFECT test to evaluate the functionality of PFM pre and post protocol of the Pilates method associated with manual therapy and isolated Pilates method.

\begin{tabular}{ccccc}
\hline & \multicolumn{2}{c}{ PTG } & \multicolumn{2}{c}{ PG } \\
& \multicolumn{2}{c}{$(\mathrm{n}=7)$} & \multicolumn{2}{c}{$(\mathrm{n}=7)$} \\
\cline { 2 - 5 } & Pre & Post & Pre & Post \\
\hline P & $2.7 \pm 0.3$ & $3.4 \pm 0.4^{*}$ & $3.1 \pm 0.2$ & $4.2 \pm 0.3^{*}$ \\
E & $2 \pm 0.3$ & $5 \pm 1^{*}$ & $2.7 \pm 0.3$ & $5.4 \pm 0.7^{*}$ \\
R & $6.5 \pm 0.7$ & $7 \pm 0.7$ & $4.4 \pm 0.5$ & $6.4 \pm 0.3^{*}$ \\
F & $7.1 \pm 0.7$ & $8.5 \pm 0.8^{*}$ & $6.2 \pm 0.7$ & $8.7 \pm 0.5^{\star}$ \\
\hline
\end{tabular}

Note: $P=$ power; $E=$ endurance; $R=$ repetitions; $F=$ fast. *Significant difference $(p<0.05)$ vs pre.

The data regarding quality of life assessed through the King's Health Questionnaire in the pre and post intervention periods are described in Table 3. In the PTG there was significance in the measures of severity, which was reduced ( $p$ $=0.01)$; disappearance of nocturia $(p=0.04)$; decreased symptoms of SUI $(p=0.02)$; decreased bladder pain $(p=0.04)$; and the total value of the test $(p=0.03)$. In the $P G$, there was a significant improvement in the perception of health $(p=0.00)$; decreased UI impact on the participant's life $(p=0.02)$; decreased of the UI influence on emotions $(p=0.00)$; decreased symptoms of overactive bladder $(p=0.01)$; decrease in SUI $(p=0.00)$; and there was relevance in the total test value for this group ( $p$ $=0.00$ ).

Table 3. Assessment of the quality of life by the King's Health Questionnaire - KHQ of the PTG and $P G$ pre and post intervention.

\begin{tabular}{|c|c|c|c|c|}
\hline & \multicolumn{2}{|c|}{$\begin{array}{l}\text { PTG } \\
(n=7)\end{array}$} & \multicolumn{2}{|c|}{$\begin{array}{c}P G \\
(n=7)\end{array}$} \\
\hline & Pre & Post & Pre & Post \\
\hline $\begin{array}{l}\text { Perception } \\
\text { of health }\end{array}$ & $\begin{array}{l}3.4 \pm 0 . \\
2\end{array}$ & $\begin{array}{l}2.7 \pm 0 \\
3\end{array}$ & $\begin{array}{l}3.4 \pm 0 . \\
2\end{array}$ & $2 \pm 0.2^{*}$ \\
\hline Ul impact & $\begin{array}{l}2.7 \pm 0 . \\
3\end{array}$ & $\begin{array}{l}2.5 \pm 0 . \\
1\end{array}$ & $\begin{array}{l}2.8 \pm 0 . \\
3\end{array}$ & $\begin{array}{l}1.2 \pm 0 \\
2^{*}\end{array}$ \\
\hline $\begin{array}{l}\text { Performanc } \\
\text { e limitations }\end{array}$ & $4 \pm 0.6$ & $3 \pm 0.3$ & $3 \pm 0.1$ & $\begin{array}{l}2.2 \pm 0 \\
2\end{array}$ \\
\hline $\begin{array}{l}\text { Physical } \\
\text { limitations }\end{array}$ & $4 \pm 0.3$ & $\begin{array}{l}3.1 \pm 0 \\
3\end{array}$ & $\begin{array}{l}3.1 \pm 0 . \\
5\end{array}$ & $\begin{array}{l}2.4 \pm 0 . \\
2\end{array}$ \\
\hline $\begin{array}{l}\text { Social } \\
\text { limitations }\end{array}$ & $\begin{array}{l}2.7 \pm 0 . \\
4\end{array}$ & $\begin{array}{l}2.2 \pm 0 . \\
1\end{array}$ & $\begin{array}{l}2.1 \pm 0 . \\
2\end{array}$ & $\begin{array}{l}2.1 \pm 0 . \\
1\end{array}$ \\
\hline $\begin{array}{l}\text { Personal } \\
\text { relationships }\end{array}$ & $\begin{array}{l}3.7 \pm 1 \\
1\end{array}$ & $3 \pm 0.5$ & $\begin{array}{l}2.5 \pm 0 . \\
7\end{array}$ & $\begin{array}{l}2.2 \pm 0 \\
3\end{array}$ \\
\hline Emotions & $\begin{array}{l}6.7 \pm 0 . \\
8\end{array}$ & $\begin{array}{l}4.7 \pm 0 \\
5\end{array}$ & $\begin{array}{l}4.8 \pm 0 \\
4\end{array}$ & $3 \pm 0.2^{*}$ \\
\hline Sleep/mood & $\begin{array}{l}3.14 \pm 0 \\
.4\end{array}$ & $\begin{array}{l}3.4 \pm 0 \\
4\end{array}$ & $\begin{array}{l}2.8 \pm 0 . \\
4\end{array}$ & $\begin{array}{l}2.2 \pm 0 . \\
1\end{array}$ \\
\hline $\begin{array}{l}\text { Severity } \\
\text { measures }\end{array}$ & $\begin{array}{l}8.5 \pm 1 \\
1\end{array}$ & $5 \pm 0.5^{*}$ & $\begin{array}{l}8.2 \pm 0 . \\
9\end{array}$ & $\begin{array}{l}5.4 \pm 0 \\
8\end{array}$ \\
\hline Frequency & $2 \pm 0.3$ & $\begin{array}{l}1.8 \pm 0 \\
4\end{array}$ & $2 \pm 0.3$ & $2 \pm 0.3$ \\
\hline Nocturia & $\begin{array}{l}0.7 \pm 0 . \\
2\end{array}$ & $0 \pm 0^{*}$ & $\begin{array}{l}0.5 \pm 0 . \\
2\end{array}$ & $\begin{array}{l}0.5 \pm 0 . \\
2\end{array}$ \\
\hline UUI & $\begin{array}{l}0.8 \pm 0 . \\
2\end{array}$ & $\begin{array}{l}0.5 \pm 0 \\
2\end{array}$ & $1 \pm 0.3$ & $\begin{array}{l}0.5 \pm 0 . \\
2\end{array}$ \\
\hline $\begin{array}{l}\text { Overactive } \\
\text { bladder }\end{array}$ & $\begin{array}{l}0.8 \pm 0 . \\
2\end{array}$ & $\begin{array}{l}0.2 \pm 0 \\
1\end{array}$ & $1 \pm 0.3$ & $0 \pm 0 *$ \\
\hline SUI & $\begin{array}{l}2.4 \pm 0 . \\
3\end{array}$ & $\begin{array}{l}1.1 \pm 0 . \\
2^{*}\end{array}$ & $\begin{array}{l}2.7 \pm 0 . \\
1\end{array}$ & $\begin{array}{l}0.7 \pm 0 \\
2^{*}\end{array}$ \\
\hline $\begin{array}{l}\text { Nocturnal } \\
\text { Enuresis }\end{array}$ & $\begin{array}{l}0.5 \pm 0 . \\
2\end{array}$ & $0 \pm 0$ & $0 \pm 0$ & $0 \pm 0$ \\
\hline $\begin{array}{l}\text { Ul in the } \\
\text { sexual } \\
\text { intercourse }\end{array}$ & $\begin{array}{l}0.2 \pm 0 . \\
1\end{array}$ & $0 \pm 0$ & $\begin{array}{l}0.1 \pm 0 . \\
1\end{array}$ & $0 \pm 0$ \\
\hline $\begin{array}{l}\text { Urinary } \\
\text { infection }\end{array}$ & $0.5 \pm 0$. & $0.1 \pm 0$. & $\begin{array}{l}0.4 \pm 0 . \\
2\end{array}$ & $0 \pm 0$ \\
\hline Bladder pain & $\begin{array}{l}0.8 \pm 0 . \\
3\end{array}$ & $\begin{array}{l}0.1 \pm 0 \\
1^{*}\end{array}$ & $\begin{array}{l}0.5 \pm 0 . \\
2\end{array}$ & $0 \pm 0$ \\
\hline Total & $48 \pm 3.6$ & $\begin{array}{l}34.1 \pm 1 \\
.5^{\star}\end{array}$ & $\begin{array}{l}41.5 \pm 2 \\
.9\end{array}$ & ${ }_{*}^{27 \pm 1.7}$ \\
\hline
\end{tabular}




\section{DISCUSSION}

The main findings of this study were: 1) the treatment with manual therapy associated with Pilates reduced the episodes of leakage of urine when there is an increase in intra-abdominal pressure, increased PFM strength, endurance and number of fast contractions, but there was no increase in the number of slow contractions; and improved quality of life in terms of decreasing severity measures, decreasing SUI, bladder pain and disappearing of nocturia; 2) Treatment with Pilates only also decreased urine leakage episodes when there was an increase in intraabdominal pressure, increased PFM strength, endurance and number of fast and slow contractions; and improved the quality of life in terms of improved health perception, decreased impact of UI, emotions, SUI, and disappearance of symptoms of overactive bladder.

Regarding predisposing factors for $\mathrm{UI}$ development, Junqueira et al. ${ }^{(16)}$ evidenced in his study with 303 hospitalized adults that having asthma increases the chances of presenting $\mathrm{UI}$ symptoms by 3.7 times. According to Marques et al. ${ }^{(17)}$, the prevalence of $\mathrm{UI}$ is higher in women who report bronchitis or asthma. Respiratory problems lead to chronic coughing or frequent sneezing that cause a repeated increase in intra-abdominal pressure and consequent overload to the pelvic floor. In our sample, $14.2 \%$ of the GP had asthma. Constipation in women with UI can cause a stretch of the rectum and compression of the bladder. When evacuating, injury to the PFM can occur and, through distension, traumatize and cause muscle ischemia. Sousa et al. ${ }^{(11)}$ observed that $42.858 \%$ of women with constipation had SUI. Similarly, in our study $28.5 \%$ of UI patients had constipation.

Another factor to be considered is regular exercise if there is a previous weakness of PFM. However, high-impact exercises that increase intra-abdominal pressure, such as weight training, favor SUI regardless of previous PFM weakness. Virtuoso et al. ${ }^{(18)}$ observed a higher incidence of urinary losses $(63.6 \%)$ in elderly women who practice gymnastics, swimming, dancing and weight training. This study was composed of 39 elderly women, 11 of whom did not practice regular physical exercise and 28 did. Most of the sample in our study performed physical exercise, between low and high intensity exercises. Other studies have also evaluated treatment protocols in patients with $\mathrm{UI}$ and have observed similar results. Knorst et al. ${ }^{(19)}$ evaluated the effects of 13 sessions of physical therapy treatment (PFM training and electrostimulation for 10 minutes) in 55 adult women and observed better urinary control, less concern about possible $\mathrm{UI}$ episodes and less restriction in carrying out daily, occupational and physical activities. Physical exercise can become a risk factor when it is not well applied. High impact physical exercise is a risk factor for the development of UI, according Patrizzi et al. ${ }^{(20)}$.

There is a relationship between $\mathrm{UI}$ in nulliparous athletes, jumping, for example, can generate a maximum reaction force that increases body weight by 16 times. This impact can compromise the ability to continent by changing the amount of force transmitted to the pelvic floor ${ }^{(21)}$. Approximately $50 \%$ of women who perform regular physical exercise in our sample performed high-impact exercises. Pregnancy and type of birth are directly linked to UI. As the pregnancy progresses, intra-abdominal pressure increases and overloads the PFM, the facial and ligament structures, which may result in the emergence of urodynamic abnormalities, irritative urinary symptoms and SUI. Stress urinary incontinence affects about 20 to $67 \%$ of pregnant women ${ }^{(22)}$. Peña and Gomes ${ }^{(23)}$ conducted a study through data collection, in which it was evidenced that episiotomy should not be a routine practice, its consequences in the short term may be: pain, increased perineal injury and greater chance of severe laceration. In the study of Rocha et al. ${ }^{(24)}$ performed with a sample of 268 women three months after their respective deliveries, the prevalence of $\mathrm{UI}$ in the postpartum period was $34.60 \%$, with SUI prevailing (82.93\%). In our sample, $14.2 \%$ of women underwent mid-lateral episiotomy during normal birth.

UI affects women's lives drastically, as shown by the study of Fernandes et al. ${ }^{\left({ }^{6}\right)}$, in which the $\mathrm{KHQ}$ was used as a method of evaluating quality of life in a sample of 305 women with UI, aged between 29 and 75 years, and presented $38.4 \%$ low quality of life. The study by Fitz et al. ${ }^{(25)}$ shows the impact of physical therapy treatment on quality of life using $\mathrm{KHQ}$ as an evaluation method. A significant decrease in the mean scores was observed in all domains assessed by the KHQ. In agreement with the results of the quality of life assessment, there was a decrease in the urinary loss and nocturnal urinary frequency of the patients, both symptoms evaluated by the voiding diary, also observed a significant increase in muscle strength and endurance.

These data corroborate those of our sample, in which we also observed an increase in PERFECT test and quality of life. With the Pilates method, a significant increase in muscle activity is 
possible, both in type 1 fibers (slow contraction) and in type 2 fibers (fast contraction) and influences the strength gradation of the pelvic floor. The activity of type 2 fibers is greater than type 1 fibers, because the voluntary contraction of the pelvic floor acts more specifically on type 2 fibers, causing them to hypertrophy, potentiating the perineal contraction force ${ }^{(26)}$. Type 1 fibers are highly resistant, although their contractile strength is relatively low. Type 2 fibers are more recruited in activities that increase intra-abdominal pressure and when a certain activity requires power, such as sneezing, coughing, weight gain and some physical exercises.

The activation of the power house consists of a contraction of the inner abdominal muscles added to the PFM co-activation, applying the voluntary contraction of the involved muscles induces an increase in intra-abdominal pressure, a slight elevation of the AP, being able to prevent and treat $S \mathrm{SI}^{(26,27)}$. As it can be seen in the present study and also in the study by Diniz et al. ${ }^{(26)}$, in which six women aged between 35 and 65 years participated, all volunteers gained muscle strength in both types of fibers, being greater in $84 \%$ of the sample in type 2 fibers. We did not find in the literature studies that have evaluated the effect of manual therapy in patients with UI. There are studies using Global Postural Reeducation (RPG) that are efficient in the treatment of UI. Cabral et al. ${ }^{(28)}$ observed that after 12 sessions with 30 minutes duration and frequency once a week in 16 women aged $59.2 \pm 8.9$ years diagnosed with SUI, there was a reduction in the levels of frequency of urinary loss and amount of urine lost after improving the function of the abdominal muscles, and there was consequently an improvement in the quality of life of these participants. These results corroborate with our findings in the present study.

However, due to the absence of studies with manual therapies in UI, our study proposed a protocol for manual manipulative techniques of the spine and sacroiliac spine adopted by Oliveira et al. ${ }^{(15)}$ who observed improvement in pain and postural changes in elderly women. We suggest that these same benefits helped UI patients, contributing to increase body and pelvic awareness, alignment and improvement of pelvic mobility acquired with Pilates.

\section{CONCLUSION}

Both treatment protocols decreased episodes of urine leakage when there is an increase in intraabdominal pressure, increased PFM strength, endurance and number of fast contractions, and increased the quality of life of women with UI. However, only the group that received only the Pilates protocol showed an increase in repetitions of slow contraction.

Author's contribution: SG and DBR: Drafting of the article, review and final approval of the article. LGAV: Drafting of the article. ASO: Conception and design of the article, review and final approval of the article.

Financial support: Nothing to declare.

Conflict of interest: The authors declare that they have no conflict of interest.

\section{REFERENCES}

1. Almeida LM. Avaliação da qualidade de vida de mulheres com incontinência urinária antes e após um protocolo de cinesioterapia para o Assoalho Pélvico. Trabalho de Conclusão de Curso. Natal: Universidade Federal do Rio Grande do Norte, 2017.

2. Gonçalves CL. Frequência de disfunções do trato urinário em mulheres no climatério. Monografia. Ouro Preto: Universidade Federal de Ouro Preto, 2018.

3. Faria CA, Moraes JR, Monnerat BRD, Verediano KA, Hawerroth PAMM, Fonseca SC. Impacto do tipo de incontinência urinária sobre a qualidade de vida de usuárias do Sistema Único de Saúde no sudeste do Brasil. Rev Bras Ginecol Obstet. 2015;37(8):374-80.

4. Gilly D. Prevalência e fatores associados à incontinência urinária, e avaliação da qualidade de vida de idosas incontinentes assistidas por uma unidade básica do sistema público de saúde da família de Recife/PE. Dissertação de mestrado. Recife: Universidade Federal de Pernambuco, 2012.

5. Frigo D, Zanon CS. Incidência da perda urinária em mulheres no climatério. Revista de divulgação científica. 2011;18(1):153-162.

6. Fernandes S, Coutinho EC, Duarte JC, Nelas PAB, Chaves CMCB, Amaral O. Qualidade de vida em mulheres com incontinência urinária. Revista de Enfermagem Referência, 2015;série-IV(5):93-99.

7. Barbosa BLA, Matos MAB, Costa MC, Rocha FCV, Almeida CAPL, Amorim FCM. As Repercussões Causadas pela Incontinência Urinária na Qualidade de Vida do Idoso. Revista de Pesquisa: Cuidado é Fundamental, 2019;11(3):567-57.

8. Brasil DMM, Nicolau AIO, Bilhar APM, Karbage SAL, Lucena SV, Carmo TF, Bezerra LRPS. Urinary incontinence and female sexual 
function: an integrative review of validated questionnaires. Acta Paul Enferm. 2018;31(5):558-63.

9. Bernardes NO. Incontinência urinária feminina e fatores de risco. Fisioterapia Brasil. 2018;7(4):301-306.

10. Tavares GF, Marques JS. Atuação fisioterapêutica em mulheres na fase de climatério com fraqueza de assoalho pélvico. VI Congresso Internacional de Envelhecimento Humano, Campina Grande PB, 2019.

11. Sousa ARS, Mendes A, Moraes BSM, Santos $\mathrm{BC}$, Matos NAF, Figueiredo CS et al. A relação da constipação intestinal e incontinência urinária em mulheres. Cadernos de Educação, Saúde e Fisioterapia. 2017;4(8).

12. Souza LM, Pergorare ABGS, Christofoletti G, Barbosa SRM. Influência de um protocolo de exercícios do método Pilates na contratilidade da musculatura do assoalho pélvico de idosas não institucionalizadas. Rev. Bras. Geriatr. Gerontol. 2017;20(4):485-493.

13. Silva ACLG, Maanrich G. Pilates na reabilitação: uma revisão sistemática. Fisioter Mov. 2009;22(3):449-55.

14. Gamarra CM. Terapia manual ortopédica en disfunciones del suelo pélvico. Lic. Arakaki villavicencio, José Miguel Akira. Lima - Peru, 2017.

15. Oliveira AS, Macedo LC, Junior JRS, Junior WRS, Vasconcelos DA. Efeitos do tratamento de quiropraxia sobre pacientes portadoras de espondiloartrose. Fit Perf J. 2008;7(3):145-50.

16. Junqueira JB, Santos VLCG. Urinary incontinence in hospital patients: prevalence and associated factors. Rev. Latino Am. Enfermagem. 2017;25:e2970.

17. Marques LP, Schneider IJC, Giehl MWC, Antes DL, d'Orsi E. Fatores demográficos, condições de saúde e hábitos de vida associados à incontinência urinária em idosos de Florianópolis. Rev Bras Epidemiol. 2015;18(3):595-606.

18. Virtuoso JF, Mazo GZ, Menezes EC. Incontinência urinária e função muscular perineal em idosas praticantes e nãopraticantes de atividade física regular. Rev Bras Fisioter. 2011;5(4):310-7.

19. Knorst MR, Lisot FE, Zollner LL, Barbosa MC , Resende TL. Influência do tipo de parto no resultado do tratamento fisioterapêutico na incontinência urinária. Revista Ciência \& Saúde. 2012;5(2):117-124

20. Patrizzi LJ, Viana DA, Silva LMA, Pegorari MS. Incontinência urinária em mulheres jovens praticantes de exercício físico. Revista Brasileira de Ciência e Movimento. 2014;22(3):105-110.

21. Caetano AS, Tavares MCGCFT, Lopes MHBM. Incontinência urinária e a prática de atividades físicas. Rev Bras Med Esporte. 2007;13(4).

22. Knorst MR, Lisot FE, Zollner LL, Barbosa MC, Resende TL. Influência do tipo de parto no resultado do tratamento fisioterapêutico na incontinência urinária. Revista Ciência \& Saúde. 2012;5(2):117-124.

23. Peña SR, Gomes CRG. Episiotomia e suas implicações. Arquivos do MUDI. 2016;20(1):25-37.

24. Rocha J, Brandão P, Melo A, Torres S, Mota L, Costa F. Avaliação da Incontinência Urinária na Gravidez e no Pós-Parto: Estudo Observacional. Acta Med Port. 2017;30(78):568-572.

25. Fitz FF, Costa TF, Yamamoto DM, Resende APM, Stüpp L, Sartori MGF, et al. Impacto do treinamento dos músculos do assoalho pélvico na qualidade de vida em mulheres com incontinência urinária. Rev. Assoc. Med. Bras. 2012;58(2):155-59.

26. Diniz MF, Vasconcelos TB, Pires JLVR, Nogueira MM, Arcanjo GN. Avaliação da força muscular do assoalho pélvico em mulheres praticantes de Mat Pilates. Manual Therapy, Posturology \& Rehabilitation Journal. 2014;12:406-420.

27. Bertoldi JT, Medeiros AM, Goulart SO. A influência do método pilates na musculatura do assoalho pélvico em mulheres no climatério: estudo de caso. Cinergis, Santa Cruz do Sul. 2015;16(4):255-60.

28. Cabral RMC, Filho GAF, Sesconetto RA, Mota YL, Pires FO. Efeitos da reeducação postural global em desvios posturais e seus benefícios nos sintomas de incontinência urinária de esforço. Revista Brasileira de Ciência e Movimento. 2015;23(2):5-13. 